\title{
Histological Analysis of Gills and Liver of Tambra Fish (Tor tambra) From Batang Gadis River in Mandailing Natal North Sumatera
}

\author{
Yusni Atifah ${ }^{1 *}$ Ramadhan Sumarmin ${ }^{1}$ Laila Tussifah ${ }^{2}$
}

\author{
${ }^{1}$ Dept. of Biology, Faculty of Mathematics and Science (FMIPA), Universitas Negeri Padang, Padang, Indonesia \\ ${ }^{2}$ Chemistry Department Faculty of Education Universitas Tapanuli Selatan, NourtSumatera \\ *Corresponding author. Email: yusniatifah@fmipa.unp.ac.id
}

\begin{abstract}
Tor tambra is one of the 10 species of fish that found in Batang Gadis River. This fish species has abundance and also the highest dominance at four observation stations in Sungai Batang Gadis. The purpose of this study was to look at the histology of gill organs and liver of Tor tambra in the Batang Gadis river. The study was conducted in June to August 2019 in the Zoology Laboratory of the Department of Biology, Padang State University. Direct observation and purposive sampling were conducted at two locations around Batang Gadis River (Tamiang and Muara Mais). Histological samples of gills and liver were isolated, fixated, dehydrated and embedded on paraffin and stained using Haematoxylin-Eosin. The results showed a number of histological changes in gill and Tambra fish liver from both locations. Those alterations varied from Melano macrophage center (MMC), hyperplasia, edema and necrosis. Those alterations varied from the two sampling locations. The level of alteration more in fish taken at station 2 (Muara Mais).
\end{abstract}

Keywords: Batang Gadis River, Gills, Histopathology, Liver

\section{INTRODUCTION}

Tambra fish (Tor tambra) is a type of freshwater fish that has high economic value. Tambray fish groups are river dwellers in tropical forests. The original habitat of Tambra fish is generally in the upper reaches of the river in hilly areas with clear air and strong currents [1]. Tambra fish is one of the 10 fish species found in Batang Gadis River. This species has abundance and is also the highest dominant in the four observation stations in Batang Gadis River [2].

Batang Gadis River is the estuary of several tributaries, namely the Lahantan river and the Batang Pungkut river originating from Mount Kulabu, Mandailing Natal Regency. This river is the longest and largest river along the Kotanopan area, while the Batang Gadis River is the main attraction of its clear water and large rocks neatly arranged. Batang Gadis River is also a very important river as a regular water provider to support the survival and main economic activities of the community, namely agriculture. Along the banks of the Batang Gadis riverbanks there are often found agricultural community areas that utilize irrigation from the Batang Gadis river flow.

Nowadays the use of pesticides is something that is difficult to separate from agricultural activities, especially in the cultivation of rice in the fields in order to increase the product both qualitatively and quantitatively. Pesticides used on rice fields, especially at the beginning of the planting season, some or even all of them will fall into the water and pollute the waters. Water that is polluted by pesticide residues when it has reached a certain concentration will greatly affect the environment and aquatic organisms that live in it.

The research results of Atifah et all [3] showed that pesticide residues in the Batang Gadis river flow in water samples, soil sediments and fish found pesticide residues from organophosphate groups namely diazinon, malation, and chlorphyrifos and from organochlorine groups namely aldrin, dieldrin and endosulfan. The highest organophosphate residues were found in the soil while the highest organochlorine residues were found in fish. The level of pesticide residues found is still at the threshold limit of pesticide residues (BMR) of pesticides.

Fish that live in a pesticide-contaminated aquatic environment will absorb the active ingredients of the pesticide and are stored in the body, because fish is a good accumulator of various types of pesticides, especially those that are lipophilic (easily bound in fatty tissue). Under sublethal water conditions, the content of pesticide residues in the body of fish formed through the bioaccumulation process will be higher with increasing concentration and increasing exposure time until reaching steady state conditions. In addition, the continued influence of pesticide bioaccumulation at certain concentrations can significantly reduce the growth rate and impact on fish haematological conditions [4].

Based on the reasons that have been stated, then research on the histological analysis of the gills and liver of Tambra fish (Tor tambra) in Batang Gadis Mandailing Natal River is important to do. This research is expected to be 
important information for efforts to preserve fish species and as one of the initial information considerations in the Batang Gadis river management policy.

\section{MATERIALS AND METHODS}

\subsection{Material}

The tools used in this study were fishing gear, basin, materials used in this study were the liver and gills of Tambra fish (Tor Tambra) and a solution to make a prefabricated paraffin method and stained using Haematoxylin-Eosin

\subsection{Method}

Fish Sampling is done at two different points. Choosing where to take samples using the porposive sampling method, namely in river areas far from agricultural areas (Tamiang) and river areas that are in agricultural areas (Muara Mais). The method used is a survey method and observation of the histological conditions of the liver and gills of Tambra fish (Tor Tambra) microscopically collected directly in the field by using purposive sampling method. Histological preparations of gills were made by the paraffin method and Haematoxylin-Eosin staining [5].

\section{RESULT AND DISCUSSION}

Based on the results of histopathological analysis of fish gills and liver there is tissue damage from mild to severe levels. With reference to the Tandjung [6], Ressang [7] and Sudiono [8] and Darmono [9] methods, the presence of MMC, edema, hyperplasia and degeneration is classified as mild damage. Congestion and hemorrhage are classified as moderate damage, whereas necrosis and anthropy are classified as severe damage. Melano macrophage center (MMC) is commonly found in all three tissues. According to Agius and Robert [10] in Ersa [11]. MMC is a collection of macrophages that contain hemosiderin, lipofuchsin and ceroids as well as the melanin pigment. MMC is found in most lymphoid tissues, most of which are caused by inflammation.

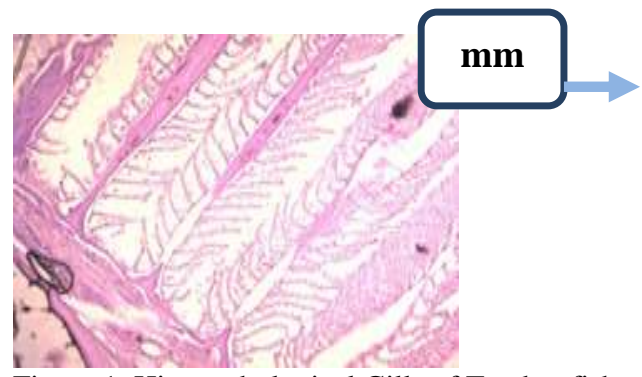

Figure 1. Histopathological Gills of Tambra fish at Station 1

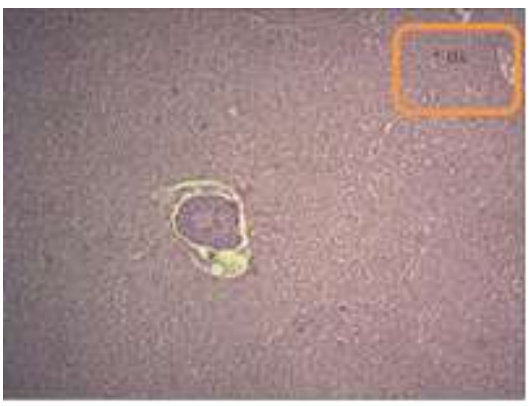

Figure 2. Histopathological Liver of Tambra fish at Station 1

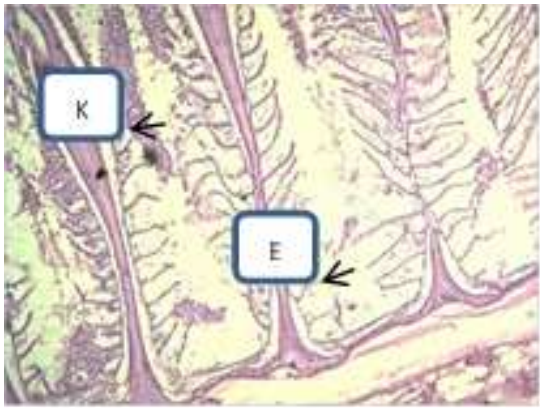

Figure 3. Histopathological Gills of Tambra fish at Station 2

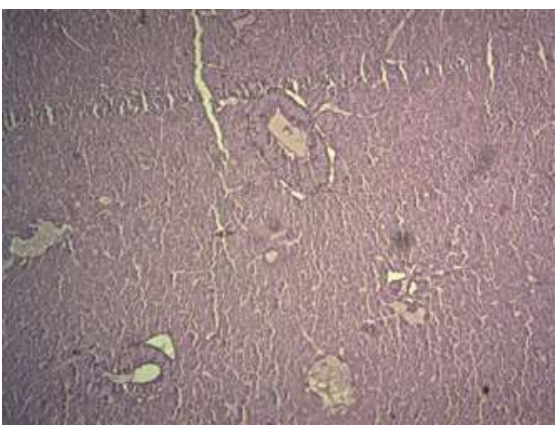

Figure 4. Histopathological livers of Tambra fish at Station 2

Histopathological observations of gills and fish liver in the river stem of the girl showed a histological change found. Changes found were different at different observation stations. At station 1 there was a change in $\mathrm{mmc}$ in the gills of the fish and degeneration of fat in the fish liver. While at station 2 there was congestion, hyperplasia and edema of the gills and hemorrhage and necrosis were found in the fish liver.

The difference in changes found at different stations shows that water conditions are different in the two sampling areas. Station 1 is a river area far from the agricultural area while Station 2 is an area found in agriculture along the river bank. The results of Atifah et al [3] showed that at station two there were found pesticide residues from organophosphate groups namely diazinon, malation, and chlorphyrifos and from organochlorine groups namely aldrin, dieldrin and endosulfan. The highest organophosphate residues were found in the soil while the highest organochlorine residues were found in fish. Although the levels found are still at the threshold limit of the pesticide residues (BMR), but the chlorpyrifos 
pesticide can last longer or is more persistent in nature than the other six pesticides, which is more than one year [12].

Organochlorine compounds are also very persistent, meaning that the active ingredients can survive in the long term either in soil, water, animal tissue, or plants. Not easily decomposed by microorganisms, enzymes, heat, or ultraviolet light. In terms of the function of pesticides, compounds with these properties are the best but not good in terms of the environment [13]. Fish that live in a pesticide-contaminated aquatic environment will absorb the active ingredients of the pesticide and are stored in the body, because fish is a good accumulator of various types of pesticides, especially those that are lipophilic (easily bound in fatty tissue). Under sublethal water conditions, the content of pesticide residues in the body of fish formed through the bioaccumulation process will be higher with increasing concentration and increasing exposure time until reaching steady state conditions. In addition, the continued influence of pesticide bioaccumulation at certain concentrations can significantly reduce the growth rate and impact on fish haematological conditions [4]. Endophytic bacteria that $(5,7)$ isolated from

\section{CONCLUSION}

Histological changes in gill and liver of Tambra fish from both locations are diffrent. Those alterations varied from Melano macrophage center (MMC), DL, hyperplasia, edema and necrosis. Those alterations varied from the two sampling locations. The level of alteration more in fish taken at station 2 (Muara Mais).

\section{REFERENCES}

[1] Haryono, and J. Subagja. 2008. Population and Habitat of Tambra fish, Tor tambroides (Bleeker, 1854) in Regional Waters Muller Mountains of Kalimantan The middle. Journal of Biodiversity. vol 9, No 4, pp. $306-$ 309

[2] Atifah, Y and Lubis, F.A. 2017. Diversity of fish species in Batang Gadis Mandailing River, North Sumatra. Scripta Biologica 4 (4): 215-219

[3] Atifah, Y., Lubis, M., Lubis., L.S., Maulana, A. 2019 Pesticide Pollution in Batang Batang Mandailing River, North Sumatra. In the process publication on Bioeducience

[4] Taufik, I. 2005. Further effects of bioaccumulation of endosulfan insecticides on growth and haematological conditions of carp (Cyprinus carpio). Thesis. Postgraduate School, Water Sciences Study Program, IPB, 83 p. the stem dan leaf (respectivly) have the ability to inhibit $S$. aureus better than other test microbes. In contrast, research conducted by(6), shows that endophytic bacteria isolated from roots can inhibit $C$. albicans better.

Although the research was done by (10)showed the endophytic bacteria can produce secondary metabolites that are the same as their hosts, even in relatively high amounts. Contrariwise, Nisa's research(9) shows that the ability of endophytic bacteria to produce antimicrobial compounds is lower than that of plant hosts. This difference in results can be caused by several factors, one of them is the use of solvents to extract active compounds which are not appropriate. In this research, the solvent used was ethanol, which is polar. According to (11), the type of solvent was a factor that influences the concentration and type of compound to be extracted. The polarity of the solvent is an important thing that influences the antimicrobial activity. Therefore, further experiments need to be carried out using non-polar solvents

[5] Suntoro, H. 1983. Metode Pewarnaan. Bhratara Karya Aksara. Jakarta

[6] Tandjung, S. D. 1995. Toksikologi Lingkungan. Gadjah Mada University Press. Yogyakarta.

[7] Ressang, A. A. 1984. Patologi Khusus Veteriner. Bali Press. Denpasar.

[8] Sudiono. 2003. Ilmu Patologi.Penerbit Buku Kedokteran. Jakarta

[9] Darmono. 1995. Metals in the System Biology of Living Things. Ui-press, Jakarta.

[10] Agius and Robert .1981. Phylogenetic development of melano-macrofage centres in fish. Journal of Zoology

[11] Ersa, I.M. 2008. Overview of Histopathology Gills, Intestines And Muscles In Fish Mujair (Oreochromis mossambicu In the Ciampea Area Bogor. Essay. Faculty of Veterinary Medicine Institut Bogor Agriculture. Bogor.

[12] Gilan, S.T. 2011. Chlorpyrifos Degradation in Soil and Its Effect on Soil Microorganisms. The Journal of Animal \& Plant Sciences.

[13] Sastroutomo, S.S. 1992. Pesticides, the basics and the impact of their use. Gramedia, Jakarta, 184 p. 